\title{
THE USE OF Arabidopsis thaliana MODEL SYSTEM FOR TESTING OIL PALM PROMOTER: CASE STUDY ON OIL PALM MT3-A PROMOTER
}

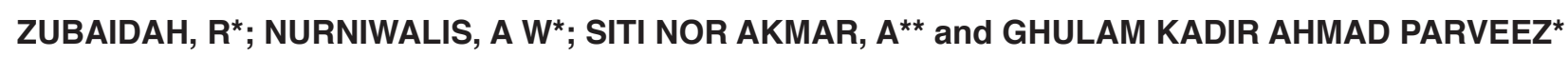

\begin{abstract}
A previous study on transient expression of oil palm tissues has shown that the oil palm metallothioneinlike type 3 (MT3-A) gene promoter is specifically expressed in the mesocarp and not in other tissues. This study was conducted to determine whether or not Arabidopsis can be used as a model system to study oil palm promoter. Functional characterisation of the oil palm MT3-A promoter was performed using promoter::GUS fusion analysis in transgenic Arabidopsis. The localisation of $\beta$-glucuronidase (GUS) expression in several different tissues of transgenic Arabidopsis homozygous lines driven by the oil palm MT3-A promoter was determined. Histochemical GUS analysis in transgenic Arabidopsis revealed the highest expression in the cotyledon and hypocotyls as well as at the early stage of plant development and gradually decreased as the plant grew. Lower expression was detected in organs of mature plant and no expression was observed in reproductive tissues. This observation may suggest that MT3-A promoter might be involved during early stage of plant development. Since we use Arabidopsis which is neither a fruit nor mesocarp plant to check mesocarp-specific promoter it might not give a faithful pattern of expression but it may be suited to study oil palm specific promoter derived from other tissues.
\end{abstract}

Keywords: oil palm, promoter analysis, model plant, $\beta$-glucuronidase.

Date received: 8 February 2017; Sent for revision: 10 February 2017; Received in final form: 20 March 2017 ; Accepted: 26 April 2017.

\section{INTRODUCTION}

One potential area that can be explored for improvement of oil palm profitability is by developing new and value-added products through genetic engineering. In order to genetically engineer oil palm, a number of tools have to be first made available. One of the absolute prerequisites is the availability of promoter sequences. The oil palm genetic engineering research at the Malaysian Palm Oil Board (MPOB) started with the aim to produce higher oleic acid content in the mesocarp.

Malaysian Palm Oil Board, 6 Persiaran Institusi, Bandar Baru Bangi,

Kajang, Selangor, Malaysia.

E-mail: bai@mpob.gov.my

** Laboratory of Plantation Crops,

Institute of Tropical Agriculture,

Universiti Putra Malaysia,

43400 UPM Serdang, Selangor, Malaysia.
Subsequently, other products were targeted which include high contents of stearic, palmitoleic, ricinoleic, lycopene as well as biodegradable plastics (Parveez et al., 2015). The promoter is responsible to initiate and regulate the transcription process of the transgene hence allowing gene expression (Billas et al., 2016). Tissue-specific promoter allows the expression of the transgene to be directed to a particular tissue where the promoter is active. In oil palm, to genetically engineer the palm to modify the mesocarp oil composition, a mesocarp-specific promoter is required. This is to ensure that the transgene is expressed in the fruit mesocarp and to avoid accumulation of the targeted products in other parts of the plant that could cause detrimental effect to the plant growth.

A cDNA clone encoding a metallothionein-like protein designated as MT3- $A$ was isolated from oil palm. Metallothionein (MT) are low molecular weight cysteine-rich protein (Rauser, 1999; Chatthai 
et al., 2004) and can be found in all organisms. The oil palm MT3- $A$ is a type 3 MT-like gene and based on previous studies, Type 3 are mainly found in developing fruit (Reid and Ross 1997; Siti Nor Akmar et al., 2002; Endo et al., 2007). Northern blot analysis showed that the gene is expressed in the mesocarp throughout the ripening period between 12 to 20 weeks after anthesis (WAA) with maximum expression at 15 WAA (Siti Nor Akmar et al., 2002). Trace level of expression was detected in kernel at 15 WAA. The MT3-A expression was not detected in young leaves but was induced in senescence leaves.

MT3-A promoter (accession No: EU499363) was isolated using genome walking approach. Eleven putative regulatory motifs were detected in the promoter sequence and all the motifs are located at specific positions upstream of the transcription start site of MT3-A (Zubaidah and Siti Nor Akmar, 2010). Transient expression analysis revealed that the activity of the oil palm MT3- $A$ promoter was only detected in the mesocarp tissue (Siti Nor Akmar and Zubaidah, 2007; 2008). Therefore, the MT3- $A$ promoter may be potentially useful for targeting expression of introduced gene into oil palm tissues especially in the mesocarp. Promoter of type 3 MT genes is important due to its fruit-specific activity (Omidvar et al., 2010). Several studies on the tissue-specificity of plant MT promoter were carried out previously (Fordham-Skelton et al., 1997; Chatthai et al., 2004). Analysis of FeMT3 promoter from buckwheat in transgenic tobacco plant revealed strong activity in the root and pollen and characterisation of rice OsMT2b promoter in transgenic Arabidopsis has led to the identification of regulatory region that is responsible for differential expression in vegetative and reproduction organs (Ren and Zhao, 2009).

Promoter fused to reporter systems is frequently used for monitoring genetic activity in plant cells. Amongst the most popular reporter systems include the firefly luciferase, $\beta$-glucuronidase (GUS) and green fluorescent protein (GFP). Transient expression assay of reporter gene was widely used to study spatial and temporal expression of plant promoters as described by several previous reports (Takahashi et al., 1992; Moriwaki et al., 1999; Crone et al., 2001; Wu et al., 2014; Jelly et al., 2014).

Since the establishment of the in vivo floral dip method for transforming Arabidopsis plants (Clough and Bent, 1998) and the completion of its genome sequence, Arabidopsis has become a very popular heterologous system for studying the function of plant genes and promoters for economically important crops such as oil palm (Zubaidah and Siti Nor Akmar, 2010; Parveez et al., 2010; 2015; Hanin et al., 2016; Siew-Eng, et al., 2016). This little plant has many advantages over other plants with its small size and simple growth habit that allows easy propagation under laboratory conditions (Anderson and Roberts, 1998). In contrast to Arabidopsis, oil palm is a parennial oil crop with a long life cycle; therefore to characterise its genes and promoters in vivo requires substantial space and time. As an alternative, it would be useful and advantageous to use model plants, for example, Arabidopsis to characterise the oil palm MT3-A promoter.

This article reports on functional characterisation of oil palm MT3-A promoter using Arabidopsis thaliana as a heterologous system. In this study, the expression profile of the MT3-A promoter was evaluated in stably transformed Arabidopsis plants as stronger evidence than the expression pattern observed from the previous transient analysis (Siti Nor Akmar and Zubaidah, 2008).

\section{MATERIALS AND METHODS}

\section{Construction of the Plasmids}

In this study, Hind III and Xba I restriction sites were introduced by polymerase chain reaction (PCR) to flank the MT3-A promoter using mspfor and msprev DNA primers (Table 1). The amplified promoter was then cloned into the promoterless pBI101 vector at the same restriction sites to yield the plasmid MSP1pro::GUS carrying GUS as the reporter gene. For comparison purposes, we also cloned the constitutive (CaMV 35S) promoter into the binary promoterless (pBI101) plasmid. The ligation procedure was performed with the Roche Cloning Kit according to the manufacturer's instructions (Roche, USA) with a few modifications (Zubaidah and Siti Nor Akmar, 2010). The resultant clones were confirmed by DNA sequencing analysis.

\section{Preparation of the Arabidopsis thaliana for Transformation}

Plants of Arabidopsis thaliana (Columbia ecotype) were grown in a mixture of two parts of Steven Dutch potting mix (Holland) and one part of vermiculite in a $9 \mathrm{~cm}$ pot and placed in the growth chamber. The plants were maintained under controlled environment as described by Zubaidah (2009), until flower buds appeared. When the first bolts appeared (four to five weeks after planting), they were removed to enhance the proliferation of many secondary bolts.

\section{Preparation of the Agrobacterium Culture}

The MSP1pro::GUS plasmid was transformed into Agrobacterium tumefaciens C58 using 
electroporation methods (Zubaidah and Siti Nor Akmar, 2010). Agrobacterium tumefaciens harbouring the desired plasmid construct was grown overnight in $20 \mathrm{ml}$ of LB broth containing kanamycin (50 $\mathrm{mg}$ litre $^{-1}$ ) and rifampicin (100 mg litre $\left.\mathrm{m}^{-1}\right)$. Agrobacterium cultures were prepared prior to in planta transformation via floral dip method (Zubaidah, 2009).

\section{In-planta Transformation}

Arabidopsis plants were dipped in Agrobacterium culture containing $1 \mu \mathrm{l} \mathrm{m} \mathrm{l}^{-1}$ silwet for 5-10 s (Zubaidah, 2009). The Arabidopsis plants were enclosed in a plastic bag and the bag was clipped at the top with a paper clip for one to two days. The plants were maintained under control environment until seed set.

\section{Selection of the Transformants}

The putative transgenic seeds were sterilised according to method as described by Zubaidah and Siti Nor Akmar (2010) and cultured on MS selection media containing kanamycin antibiotic (50 mg litre $^{-1}$ ) (Murashige and Skoog, 1962). Healthy surviving plants were transferred individually to soil to select homozygous lines for further analysis. The status of the transgenic Arabidopsis plants was further verified using PCR (as described in the section verification of the transformants).

\section{Selection for Transgenic Homozygous Lines}

Sixteen plants from each line (T2 generation) were planted individually in $9 \mathrm{~cm}$ pots until seed set. The seeds (T3 generation) from each individual lines were collected and screened for kanamycin resistance. Plates containing all plants that survived were considered homozygous lines. All homozygous lines were selected for further analysis.

\section{Verification of the Transformed Plant}

PCR method was used to confirm the introduction of the oil palm MT3-A promoter into the Arabidopsis genome with the correct orientation. In this study, DNA was extracted from leaf tissues of each individual transgenic line using

TABLE 1. LIST OF PRIMERS USED FOR AMPLIFICATION AND VERIFICATION OF THE MT3-A PROMOTER

\begin{tabular}{ll}
\hline $\begin{array}{l}\text { Primer } \\
\text { name }\end{array}$ & \multicolumn{1}{c}{ Sequence } \\
\hline Mspfor & 5'-CTG CCA TGG AGG GTC ACA ATG ATG -3' \\
Msprev & 5'-GAC GAA TAA TCC GGA AGG AAT CTG-3' \\
GUSrev & 5'-TCA CGG GTT GGG GTT TCT AC-3' \\
\hline
\end{tabular}

Plant DNAeasy Kit (Qiagen, USA) and PCR was performed using gene specific primers (mspfor and msprev) and mspfor and GUSrev that have been designed based on MT3-A promoter and GUS sequences. These primers are listed in Table 1.

\section{Expression Studies via GUS Assay}

GUS activity was determined using histochemical staining as described by Jefferson et al. (1987) with minor modifications (Zubaidah and Siti Nor Akmar 2010). The treated tissues were observed under a light microscope (Nikon SMZ800, Japan).

\section{RESULTS AND DISCUSSION}

\section{Generation of the Transformation Vector Containing the Oil Palm MT3-A Promoter}

The Hind III and Xba 1 restriction sites were introduced by PCR to flank the MT3- $A$ promoter region. The PCR reaction generated a $950 \mathrm{bp}$ product as expected. This product was then ligated into the promoterless pBI101 plasmid at the same restriction sites. The resulting clone was designated as pBMS::GUS construct which contained the MT3- $A$ promoter. The recombinant was digested with Hind III and Xba I restriction enzymes to confirm the presence of the insert. Restriction digestion analysis confirmed the presence of the expected insert size (lanes 2-5) in the clone containing the MT3- $A$ promoter as shown in the Figure 1. Further verification of the pBMS::GUS clone was performed by DNA sequencing analysis.

\section{Agrobacterium-mediated Transformation of Arabidopsis}

In this study, we determined that factors such as the age, health and vigour of the plants used as well as the developmental stage of the flower buds have affected the transformation efficiency (Weigel and Glazebrook, 2002). The healthy five-week-old plants with density of 8 to 10 plants per pot (Figure $2 a$ ) with unopened flowers (Figure $2 b$ ) and prior to the emergence of siliques are the best parameters to enhance the transformation efficiency. In addition, higher transformation rate was achieved when the first batch of flower buds was removed because it would increase the density of the flower buds per plant.

\section{Selection and Verification of the Transformants}

The transformed seeds were germinated and produced healthy growing plants on selection media (Figure 3) while the untransformed 


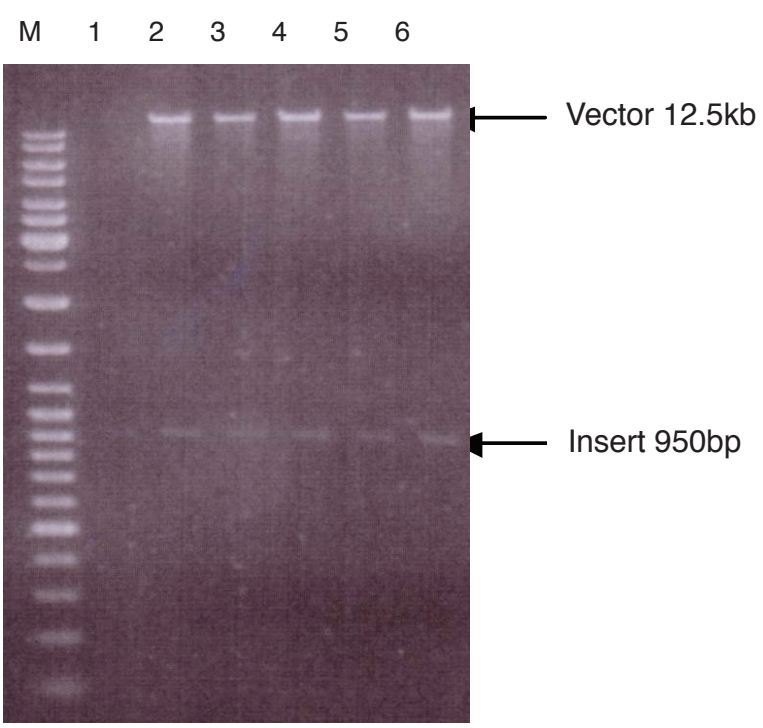

Figure 1. Restriction digestion analysis of the constructed plasmid (pBMS:GUS). Lane $M$ is the DNA ladder mix marker. Lane 1 is the negative control and lanes 2-6 constructed plasmid with the expected insert size (950 bp) and the vector (12.5 kb).

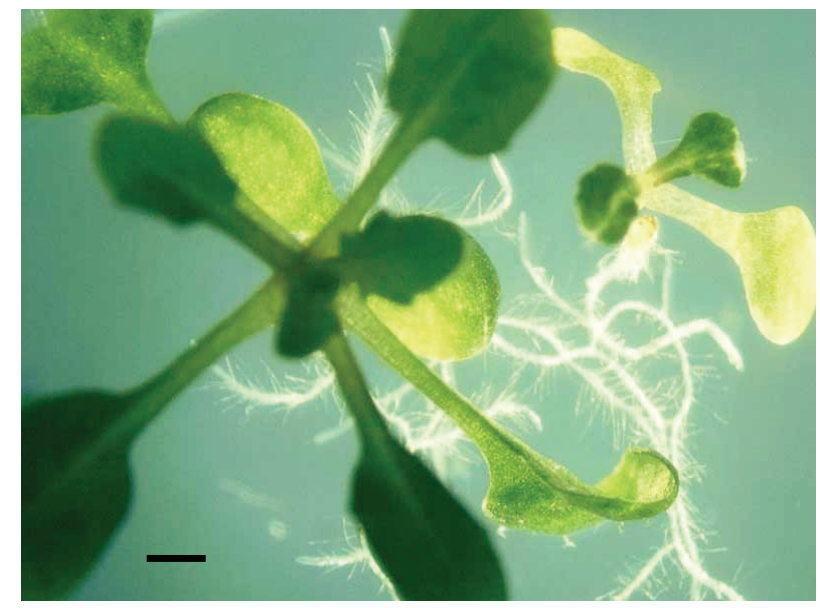

Figure 3. Healthy growing transformed Arabidopsis plant (left)

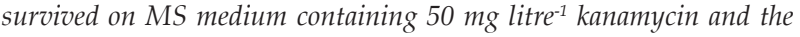
yellowish untransformed plant (right). Bar $=1 \mathrm{~mm}$.

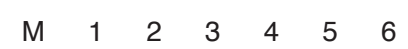

(a)

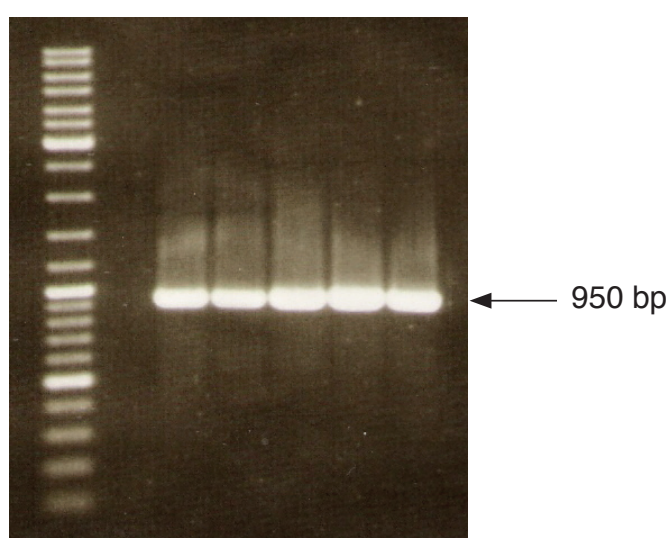

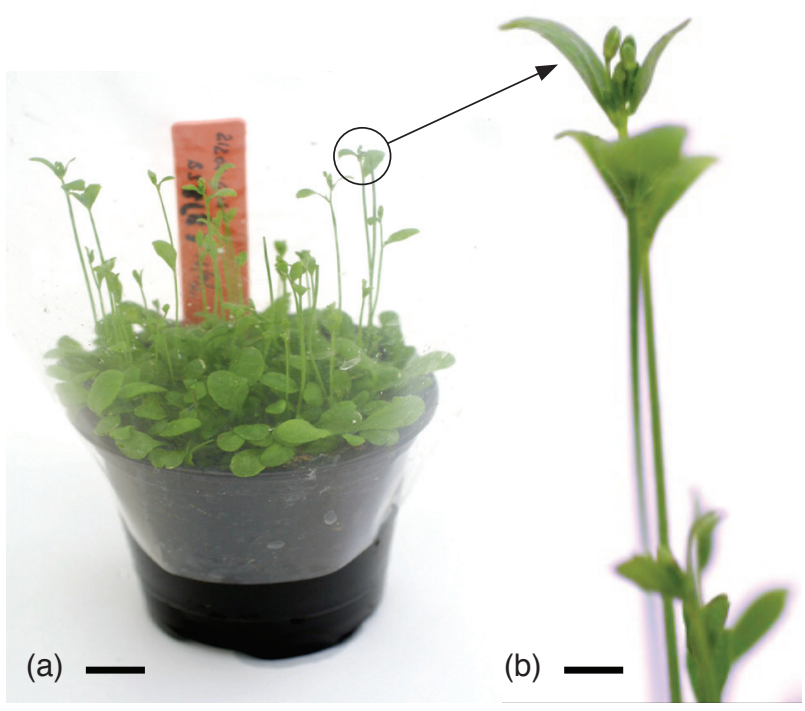

Figure 2. The best developmental stage of Arabidopsis thaliana plant for Agrobacterium-mediated transformation. (a) Bar $=1 \mathrm{~cm}$; (b) bar $=1 \mathrm{~mm}$.

seeds remained as yellowish plants and would not survive on selection media. Surviving plants were transferred individually to soil to select for homozygous lines prior to further analysis. The status of the transgenic Arabidopsis plants was further verified using PCR. DNA was extracted from leaf tissues of the transgenic Arabidopsis and PCR reactions were conducted using two different sets of primers. Positive results were obtained from all the plant tested (Figures $4 a$ and $4 b$ ).

\section{Spatial and Temporal Expression Pattern of the Oil Palm MT3-A Promoter}

In this study, an Arabidopsis plant was used as the model system for analysing the strength and specificity of the oil palm mesocarp-specific $(M T 3-A)$ promoter. Several transgenic homozygous

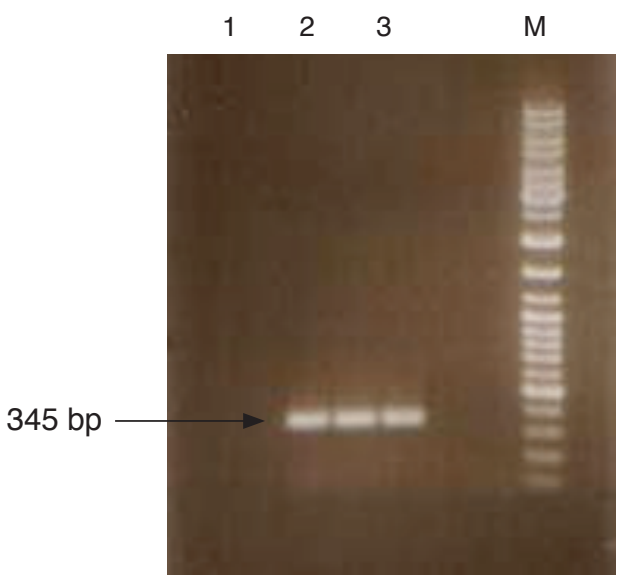

Figure 4. (a) Example of polymerase chain reaction (PCR) analysis of PCR analysis of ProMSP1::GUS transgenic plant with the amplification of about $1 \mathrm{~kb}$ expected band using MT3-A specific primers. Lane $M$ is the $1 \mathrm{~kb}$ marker; lane 1 is the negative control and lanes 2 to 6 are the transgenic Arabidopsis carrying MT3-A promoter. (b) PCR analysis of the transgenic plant carrying the same construct with MT3-A specifc primer and $\beta$-glucuronidase (GUS) primer (lane 1 -3), lane $M=$ marker $1 \mathrm{~kb}$ ladder. 
lines containing the oil palm MT3-A promoter were generated. Expression of the GUS gene from T3 homozygous transgenic lines were obtained from six independent lines. Analysis of the transgenic homozygous lines revealed that GUS expression was highest in the cotyledon and hypocotyls especially at the aerial part of the seedlings (Figures $5 a$ to $5 d$ ). As the plant grew to maturity, lower GUS expression was observed in leaf and no expression detected in stem tissues. GUS expression was also absent in reproductive tissues such as flower, silique and pollen (Figures $5 e$ to $5 g$ ). The overall expression pattern showed that MT3-A expression was only found in actively dividing hypocotyls, cotyledon and leaf tissues suggesting that this gene might be involved in cell division and plant development. Figure $6 a$ shows the GUS expression pattern driven by the oil palm MT3- $A$ promoter observed in transgenic Arabidopsis. GUS expression was mainly observed in aerial tissues compared to transgenic Arabidopsis plants carrying the constitutive CaMV $35 S$ promoter (Figure $6 b$ ) where the GUS expression was constitutively expressed in all tissues. A previous study on MT gene of Brassica napus L. also showed similar pattern of expression with highest MT expression levels in cotyledon tissues while mature organs exhibited lower levels and no expression was observed in flower (Dabrowska et al., 2013).

MT-3 type gene expression was also apparent in young, extensively growing seedling as opposed to organs of mature plant (Dabrowska et al., 2012). However, based on transient expression pattern of oil palm tissue slices using GUS as reporter gene (Siti Nor Akmar and Zubaidah, 2008) indicated that GUS expression was only observed in mesocarp tissue but absent in matured leaf. However, MT-3 type gene expression occurs predominantly in fleshy fruit but can be observed in other organ of plants lacking such kind of fruit, such as leaf tissues in Arabidopsis thaliana (Gou et al., 2003). Another possibility is that the size of the isolated oil palm promoter (MT3-A) of about $1 \mathrm{~kb}$ might not drive faithful expression in the Arabidopsis system. In addition, Arabidopsis may not be the best system to study a fruit or mesocarp-specific promoter in contrast to the study on oil palm leaf-specific promoter (Hanin et al., 2016).

In this study, the use of model plant species clearly does not provide data that would be as robust as that obtained by using expression in oil
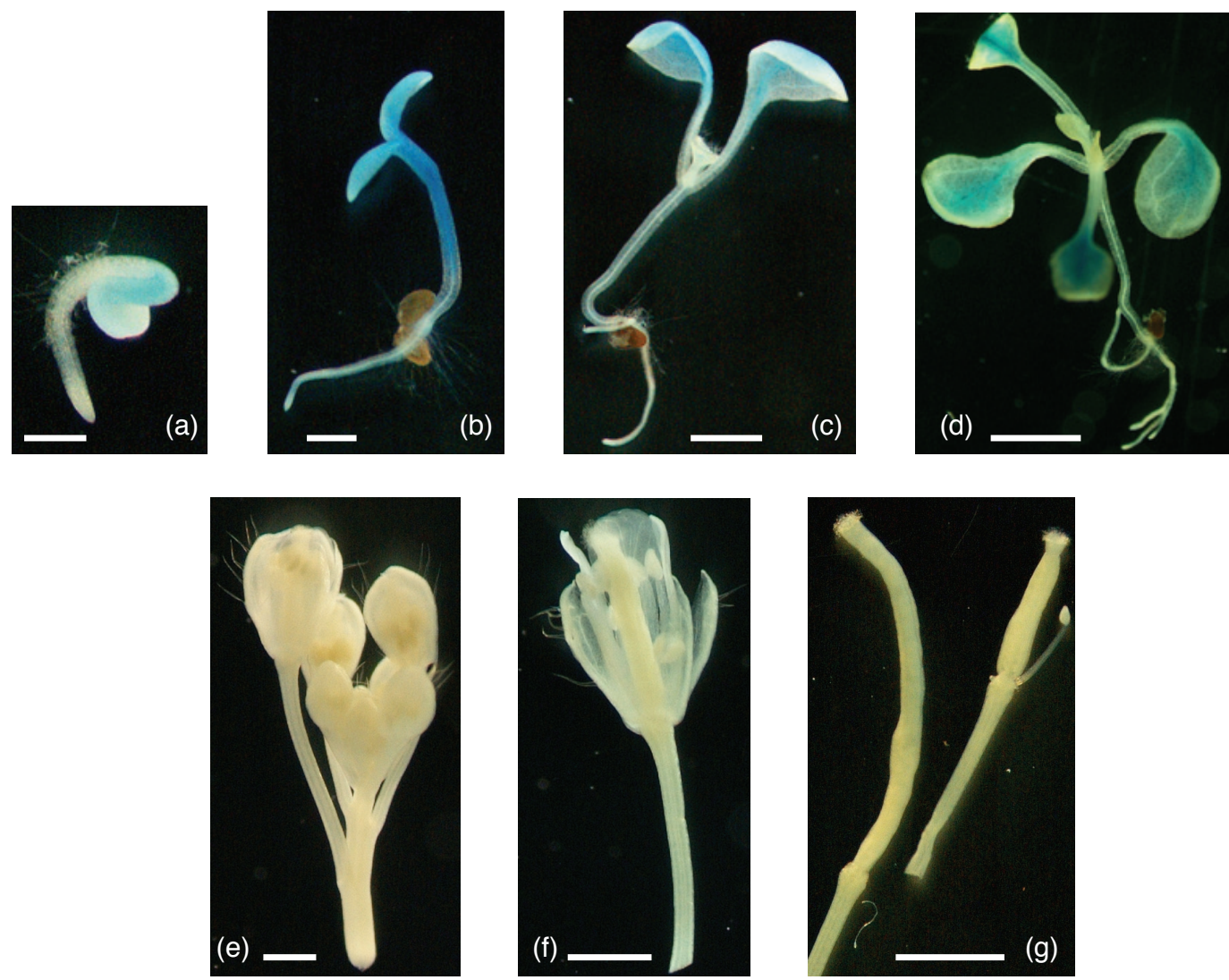

Figure 5. The $\beta$-glucuronidase (GUS) staining patterns in the aerial part of the seedling. (a) GUS expression in the plumule of four days old germinated seedling; (b) Expression in hypocotyl and cotyledon; (c) Expression observed in seedling at two leaf rosette stage; (d) GUS expression in the transgenic seedling at four leaf stage. No GUS expression was observed in other tissues: (e) flower buds; ( $f$ ) open flower and ( $g$ ) siliques. a and b, bar $=250 \mu \mathrm{m}$; $c, e$ and $f$ bar $=1 \mathrm{~mm} ; d$ and $g$, bar $=1 \mathrm{~cm}$. 

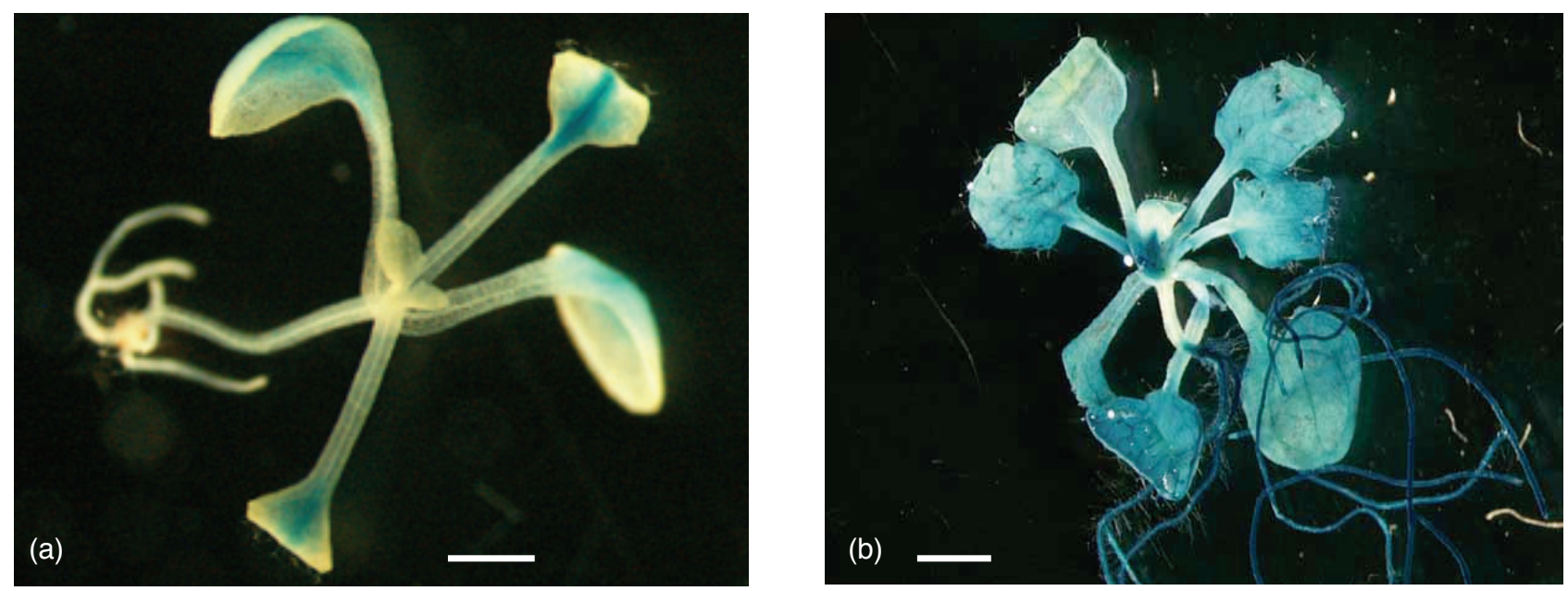

Figure 6. Comparison of $\beta$-glucuronidase (GUS) expression driven by the oil palm MT3-A promoter (a) and constitutive CaMV $35 S$ promoter (b). Bar=1 cm.

palm itself. Moreover, a monocot promoter might not provide faithful representation of expression in a dicot model species especially in certain tissues. Currently, systems to transform oil palm are somewhat limited and it can take one to two years from transformation to obtain transgenic seedlings (Parveez et al., 2015). The duration and efficiency of the process will no doubt improve over the coming years and it is hoped that GUS analysis in oil palm transgenic plant may become more routine in future.

\section{CONCLUSION}

This study demonstrated that Arabidopsis thaliana provides some opportunities for studying oil palm gene expression. However, it is also evident that there may be limitations using Arabidopsis for studying oil palm genes and promoters. Therefore, careful interpretation and extrapolation of observations to the oil palm crop is needed. Use of a longer promoter may provide additional support or generate a more faithful expression of the gene. The use of other model systems for testing oil palm promoters such as the fleshy fruit, for example tomato, can be explored in future.

\section{ACKNOWLEDGEMENT}

The author would like to thank the Director-General of MPOB for permission to publish this article. We appreciate the help of Dr Abrizah Othman and Dr Ooi Siew Eng for critically reviewing this manuscript. We would also like to thank Khairul Anuar Rahman and Mahadzir Jaafar for their technical assistance.

\section{REFERENCES}

ANDERSON, $\mathrm{M}$ and ROBERTS, J A (1998). Arabidopsis. Sheffield Academic Press, Sheffield, England.

BILLAS, R; SZAFRAN, K; HNATUSZKAKONKAR, K and KONONOWICZ, A (2016). A cis regulatory elements used to control gene expression in plant. Plant Cell Tiss Organ Cult, 127: 269-287.

CHATTHAI, M; OSUSKY, M; OSUSKA, L; YEVTUSHENKO, D and MISRA, S (2004). Functional analysis of a Douglas-fir metallothionein-like gene promoter: transient assays in zygotic and somatic embryos and stable transformation in transgenic tobacco. Planta, 220: 118-128.

CLOUGH, S J and BENT, A F (1998). Floral dip: a simplified method for Agrobacterium-mediated transformation of Arabidopsis thaliana. The Plant J., 16(6): 735-743.

CRONE, D; RUEDA, J; MARTIN, K L; HAMILTON, D A and MASCERENHAS, J P (2001). The differential expression of a heat-shock promoter in floral and reproductive tissues. Plant, Cell and Environments, 24: 869-874.

DABRAOWSKA, G; MIEREK-ADAMSKA, A and GOC, A (2013). Characterisation of Brassica napus L., mettallothionein genes (BnMTs) expression in organs during seed germination. Australian J. Crop Science, 7(9): 1324-1332.

DABRAOWSKA, G; MIEREK-ADAMSKA, A and GOC A (2012). Plant metallothioneins: putative functions identified by promoter analysis in silico. 
Acta Biologica Cracoviensia Series Botanica, 54: 109120.

ENDO, T; SHIMADA, T; FUJII, H; MORIGUCHI, T and OMURA, M (2007) Promoter analysis of a type 3 metallothionein-like gene abundant in Satsuma mandarin (Citrus unshiu Marc.) fruit. Sci Hortic, 12: 207-214.

FORDHAM-SKELTON, A P; LILLEY, C; URWIN, P E and ROBINSON, N J (1997). GUS expression in Arabidopsis directed by 50-regions of the pea metallothionein-like gene PsMTA. Plant Mol Biol, 34: 659-668.

GUO, WJ; BUNDITHYA, W and GOLDSBOROUGH, P B (2003). Characterisation of Arabidopsis metallothionein gene family: tissue-specific expression and induction during senescence and in response to copper. New Phytology, 159: 369-381.

HANIN, A N; MASANI, M YA and PARVEEZ, G K A (2016). Evaluation of leaf-specific promoter (LSP1) activity for expressing PHB gene in Arabidopsis thaliana. J. Oil Palm Res. Vol. 28(1): 1-9.

JEFFERSON, R A; KAVANAGH, T A and BEVAN, M V (1987). GUS fusions: glucuronidase as a sensitive and versatile gene fusion marker in higher plants. EMBO J., 6(13): 3091-3097.

JELLY, N S; VALAT, L; WALTER, B and MAILLOT, $P$ (2014). Transient expression assays in grapevine: a step towards genetic improvement. Plant Biotechnology J., 12: 1231-1245.

MORIWAKI, M; YAMAKAWA, T; WASHINO, T; KODAMA, T and IGARASHI, Y (1999). Organspecific expression of $\beta$-glucuronidase activity driven by the Arabidopsis heat-shock promoter in heat-stressed transgenic tobacco and Arabidopsis plants. Plant Molecular Biology, 28: 73-82.

MURASHIGE, T and SKOOG, S (1962). A review medium for rapid growth and bioassays with tobacco tissue cultures. Plant Physiology, 15: 473-497.

OMIDVAR, V; ABDULLAH, S N A; IZADFARD, A; HO, C L and MAHMOOD, M (2010) The oil palm metallothionein promoter contains a novel AGTTAGG motif conferring its fruit-specific expression and is inducible by abiotic factors. Planta, 232(4): 925-936.

PARVEEZ G K A; RASID, O A and MASANI, A M Y (2015). Biotechnology of oil palm: strategies towards manipulation of lipid content and composition. Plant Cell Rep., 34: 533-543.
PARVEEZ, G K A; ABRIZAH, O; NURHAFIZAH, R and BAHARIAH, B (2010). Functional analysis of oil palm palmitoyl-ACP thioesterase (Fat B) via downregulation in model plant: Arabidopsis thaliana. J. Oil Palm Res. Vol. 22: 803-813.

RAUSER, W E (1999). Structure and function of metal chelators produced by plants: the case for organic acids, amino acids, phytin, and metallothioneins. Cell Biochem Biophysiol, 31: 19-48.

REID, S J and ROSS, G S (1997). Up-regulation of two cDNA clones encoding metallothionein-like proteins in apple fruit during cool storage. Plant Physiol, 100: 183-189.

REN, Y and ZHAO, J (2009). Functional analysis of the rice metallothionein gene $O s M T 2 b$ promoter in transgenic Arabidopsis plants and rice germinated embryos. Plant Sci., 176: 528-538.

SIEW-ENG OOI; ZUBAIDAH RAMLI; SHARIFAH SHAHRUL RABIAH SYED ALWEE; HARIKRISHNA KULAVEERASINGAM and MEILINA ONG-ABDULLAH (2016). EgHOX1, a HD-Zip II gene, is highly expressed during early oil palm (Elaeis guineensis Jacq.) somatic embryogenesis. Plant Gene J., 8: 16-25.

SITI NOR AKMAR ABDULLAH; CHEAH, S C and MURPHY, D Y (2002). Isolation and characterisation of two divergent type 3 metallothioneins from the oil palm, Elaeis guineensis. Plant Physiology and Biochemistry, 40(3): 255-263.

SITI NOR AKMAR, A and ZUBAIDAH R (2007). Regulatory sequences for regulation of gene expression in plants and other organisms, and compositions, products and methods related thereto. United States patent US 7,173,120 b2.

SITI NOR AKMAR, A and ZUBAIDAH, R (2008). Mesocarp-specific metallothionein-like gene promoter for genetic engineering of oil palm. J. Oil Palm Res. Vol. 2: 1-8.

TAKAHASHI, T; NAITO, S and KOMEDA, Y (1992). The Arabidopsis HSP18.2 promoter / GUS gene fusion in transgenic Arabidopsis plants: a powerful tool for the isolation of regulatory mutants of the heat-shock response. The Plant J., 2(5): 751-761.

WEIGEL, D and GLAZEBROOK, J (2002). Arabidopsis. A Laboratory Manual. Cold Spring Harbor Laboratory Press Cold Spring Habor, New York.

WU, H-Y; LIU, K-H; WANG, Y-C; WU, J-F; CHIU, W-L; CHEN, C-Y; WU, S-H; SHEEN, J and LAI, 
E-M (2014). AGROBEST: an efficient Agrobacteriummediated transient expression method for versatile gene function analyses in Arabidopsis seedlings. Plant Methods, 10(19): 1-16.

ZUBAIDAH RAMLI (2009). Strategies to Dissect the Roles of Oil Palm Genes Using Arabidopsis as a Model
Plant. Ph.D thesis, University of Nottingham, United Kingdom.

ZUBAIDAH RAMLI and SITI NOR AKMAR ABDULLAH (2010). Functional characterization of the oil palm type 3 metallothionien-like gene (MT3-B) promoter. Plant Molecular Biology Reporter, 28: 531-541. 